\title{
Book Review: Das Jahrhundert der Politik. Eine Geschichte des 20. Jahrhunderts im Lichte ihrer Politikbegriffe by Friedbert Rüb, Nomos, 2020, 682 pages. ISBN: 978-3- 8487-6613-0
}

\author{
Kari Palonen \\ Department of Social Sciences and Philosophy, University of Jyväskylä, FI \\ kari.i.palonen@jyu.fi
}

Keywords: Friedbert Rüb; The concept of politics; the century of politics; philosophy of history; politics as subsystem of the society

What happened to politics in the twenty-first century? What kind of significance did politics have in the twentieth century? These are the two massive if not impossible questions, which Friedbert Rüb, an emeritus professor of Political Science at the Humboldt Universität zu Berlin, has dared to look for an answer to with a thick book of 682 pages.

The former question has been discussed in numerous other works, most recently in those referring to the 'populist moment', a term that, for example, Chantal Mouffe uses in her For a Left Populism (2018). She praises all sorts of populisms as an expression of polarisation that dissolves the stagnant consensus of the established centre-left and centre-right parties. Her argumentation is hardly convincing: the consensus thesis expresses her disinterest or lacking political literacy for the multiple differences within the governmental mainstream of West European parties, which do not any longer correspond to the traditional divisions of isms.

Friedbert Rüb judges the current populist and nationalist wave of the twenty-first century much more pessimistically. He even speaks of a disappearance of politics, although putting das Verschwinden in quotation marks. In the final paragraph of the book, Rüb characterises the present-day politics as running after the conditions instead of shaping them (das Nachlaufen hinter den Verhältnissen und nicht durch ihre Neugestaltung) (p. 635). This conclusion is not convincing but illustrates Rüb's own view on politics and to its central position in the twentieth-century European and world history.

In other words, Rüb's book is not merely an analysis of the contemporary situation with an extensive discussion of its background. More interestingly, he presents an ambitious historico-philosophical thesis on the twentieth century as the century of politics. I question such an enterprise, mainly for the reason of Rüb's Hegelian style of discussing politics as a part of all-encompassing and totalising philosophy of history. Nonetheless, his thesis is original and deserves to be discussed. 
Of course, the twentieth century has got many global characterisations, such as the century of technology or of economy. To label it as a century of politics is a provocative thesis worth taking a closer look. Although the formula seems to be Rüb's own, the idea can be traced back to the work of his late Hamburg colleague Michael Th. Greven, who spoke of 'the political society' (die politische Gesellschaft) (see his books Die politische Gesellschaft, 1999, and Kontingenz und Dezision, 2000).

Rüb's initial thesis is the formation of the 'political society' as a new type of society (p. 23). This claim already subsumes the activity of politics into the category of 'society' as a totality, which can have different qualifications. This is part of his discussion of the relative significance of politics - as a specific sphere of action - within the 'total' frame of 'the society'.

Even if Rüb in the first part of the book frequently quotes me, our disagreement arises with this subordination of politics to a totality, called 'the society'. After reading Hannah Arendt's Vita activa in Berlin in 1981, I started to count myself among the 'anti-societal elements'. In the minimal sense this does not mean more than that during the 40 years I have managed to set the figure of 'society' under the Occam's razor, that is, avoided for myself using it without quotation marks. There is no necessity to use it more than any other concepts. In a more ambitious sense, my rejection of 'the society' means a dissent with any Hegelian style total view. With the Sophists, Nietzsche and in particular Max Weber, I share a perspectivist vision of the world, in which politics, as a way of acting and thinking, forms a distinctive perspective in which I am one-sidedly interested (see esp. my books Das 'Webersche Moment', 1998, and 'Objektivität' als faires Spiel, 2010). For other perspectives, however named, I am, as a scholar, not interested in. I find historico-philosophical speculation of the relative significance of politics misleading, although not always uninteresting.

Rüb immediately formulates the principle how the distinctive political quality manifests itself. The concept refers to the 'idea of goal-directed political steering of modern societies' (Idee der zielgerichteten politischen Steuerung der modernen Gesellschaften). This contains an imagination of realisability of the steering (Machbarkeitsphantasie (pp. 23-24), which did not appear before the twentieth century. The 'century of politics' is for Rüb no ideal state of affairs but contains strong reservations against the unwanted consequences of extreme forms of 'political society'.

Why does he identify the activity of politics with the goal-directed steering? One of the initial formulations emphasises that it was the political actors who thought central ideologies and programmes of the century and they were planned to be realised through politics (mittels Politik) (p. 24). This gives hint to a kind of systems theoretical view: politics as a complex of actions forms for him the steering subsystem of the society, which is necessary for enabling changes, and he even uses the classical terminus Primat der Politik (p. 32) for his own purposes. Rüb will study the century of politics through the political semantics (p. 25), which includes the languages of both actors and theorists, or styles of thinking, as he puts it with a reference to Karl Mannheim (p. 27).

Friedbert Rüb calls the narrative that he presents in his extensive book a 'caleidoscopic picture' (p. 26) of a number of topoi, which contain both forms of action and fields of action, qualified by the concept of contingency, a term he shares with Greven and me (p. 30). He has adopted from my works the term Handlungsbegriff as well as the identification of the origins of this way of conceptualising politics around 1900 (p. 31). However, for him only those activities count, which can be included within the polity as the steering subsystem of the society.

Rüb arrives to a distinctive perspective on what happened for the concept of politics during the twentieth century. He presents it in Chapters 2-13 of the volume, after a militant polemic against Carl Schmitt, justifying why he prefers - again in accordance with Greven and me but on very different grounds - to speak of politics rather than on the political. To 
illustrate both the range of interests in Rüb's book I quote a short version of the chapter titles, which already indicates a certain sense of arbitrariness in his inclusion and naming of the forms and fields of politics. For his kaleidoscopic narrative the chosen topoi are presented as something evidently important by themselves, without any typological comparisons of what deserves to be discussed or alternatives for naming them. At the end I will come back to the question, what has been excluded from the list and why. The main chapter titles are the following ones:

2. Politik der Möglichkeitserweiterung und Kontingenzsteigerung (The politics of extension of possibilities and accentuation of the contingency)

3. Die Politik der Verfassung (The politics of the constitution)

4. Die Politik der Massen (The politics of the masses)

5. Die Politik des Sozialen (The politics of the social)

6. Die Politik der Paranoia (The politics of the paranoia)

7. Die Politik des Tötens (The politics of the killing)

8. Die Politik des Krieges (The politics of the war)

9. Die Politik des Friedens (The politics of the peace)

10. Die Politik der Rationalität und ihr Scheitern (The politics rationality and its failure)

11. Die Politik der Parteien (The politics of the parties)

12. Die Politik und ihre Variationen durch Politikertypen (The politics of the various types of politicians)

13. Die Politik mit dem Bild and die Politik des Bildes (The politics with image should be in the singular in the both cases, as it is in the German version).

The list remains quite disturbing: not only are the topoi hardly comparable with each other as I attempted to deal with my nine topoi in The Struggle with Time, 2006. Some of the titles raise the question do they deserve to be included in the list and still others whether they deserve to be called politics at all (especially Chapters 6. and 7.). I don't deny that many of the chapters might offer rather interesting reading experiences and take up some texts and debates I was not so familiar with. The most disappointing is the short chapter (Chapter 12) on the types of politicians, which misses most of the interesting debates on the topic.

Let's start with Rüb's initial moment, by which he justifies how and why the action-concept breaks with the old view of politics realising of pre-given goals, such as good life or reason of the state. 'Politik verwandelt sich zu einer Aktivität, die neue Spielräume schafft, das Gegebene in Frage stellt, neue Möglichkeiten eröffnet - und durch eine politische Entscheidung diesen Möglichkeitshorizont vorläufig schließt' (p. 63). Politics thus both opens new possibilities for playing and decides to close some of them for the moment. Or, to formulate it in my own terms (see 'Four Times of Politics, Alternatives 28, 2003): politics consists of politicising opening for chances for politicking and limits them in a definite polity by the decisions of closing momentarily a part of them with definite policies. Where lies then the difference? For me 'politics' as an action-concept marks an umbrella term for the four aspects. It opened up by the individual politicising moves, which enable politicking but are for the being limited by the existing polity and the policies available within it. For Rüb politics as activity is merely a term for the novelty in a system (polity-subsystem of the totality of 'the society'), to which individual moves of action are subordinated.

Such a systemic view enables him to speak of the century of politics, as something in which the weight or significance of politics was superior to all other subsystems. It allows him also to identify the origins of the century of politics in a rather surprising way, namely in an article of the journal Zeitschrift für die gesamte Staatswissenschaft that its editor, the economist 
Albert Schäffle published, at the request of the readers, in 1897 (p. 64). Rüb speaks for the Schäfflean moment that originates the century of politics. Politics is for Schäffle 'something fluid, becoming, change, a decision to be taken, by something to be created', and it is opposed the routine forms of state actions (laufendes Staatsleben) (ibid.).

Rüb rightly emphasises that Schäffle understood the contingency of politics, marking a break with the tradition. He presents this claim without comparing his work with other hints to contingency that can be found in the politics literature of the nineteenth century, for example, in the writings of Clausewitz and Tocqueville. He connects Weber to Schäffe's discussion of contingency but does not direct attention to Weber's concept of Chance in his 'Objektivität' essay of 1904, which marks an openness of the situation that cannot just be closed by a decision and thus marked me the momentum for something new. For Weber, politics is an activity of plural actors playing with various Chancen as their power shares (Machtanteile), as made clear his later works, including Politik als Beruf (1919), the only text of Weber that Rüb quotes.

The systemic frame of the activity of politics, the emphasis on the decisions to close the contingent action by more or less radical means, is obvious in all the other topoi of politics in Rüb's narrative. The single-actor paradigm appears clearly in the 'politics of the social' - the benefiters of social policy are hardly recognised as political actors. The political murders and suicide attentats (Chapter 6) drive the asymmetry between the 'maker' with the 'target' to the extreme as do in a different sense the totalitarian 'politics of killing', especially in the Nazi version (Chapter 7). Rüb quotes Hannah Arendt's view from The Origins of Totalitarianism against the 'everything is possible' (p. 322), which does not refer to contingency but to a total and controlled manipulability of both humans and things. For Arendt, such 'fabrication' is, as it is well known, an antithesis of politics as action, and nothing shows better than the industrial 'fabrication of dead bodies' in the extermination camps. Rüb recognises that for both Nazi and Soviet totalitarianism politics was no independent action but justified by so-called 'laws' of biology, respectively, of history, which can be regarded as a very negation of the idea of the contingency of political action, even within the single-actor model.

Carl von Clausewitz's classical view on war as a continuation of politics by other means includes a certain respect for the enemies, at least their recognition as independent actors. In the twentieth century, Rüb emphasises how both the 'total war' theorised by Erich Ludendorff as well as the atomic war did not allow for their proponents the possibility of losing the war. Although the loss was thought as possible, the intended pre-determination of the result depoliticises the adversaries and thus at least raises a question mark on war as a form of politics.

The three chapters offer extreme examples of a kind of politics against politics of terminating the contingency and not allowing any dissent or dispute. More interesting is that Rüb, in a sense, also says the same of the politics of rationality. He opposes the optimistic systems theory of Karl Deutsch in favour of increased political steering of 'the society' to Niklas Luhmann, who denies such possibility and thus denies the priority of politics.

With a slight simplification we could say that Rüb's thesis on the end of the century of politics is justified in terms of the Luhmannian systems theory, which regards the subsystem of politics merely as an ex post adaptation to the existing conditions of 'the society': for Luhmann politics is always 'too late' (pp. 526-531). The great projects for change from the twentieth century disappear and with them also politics (pp. 626-633). Rüb is not willing to give up the steering and rationality paradigms despite recognising their irreparable failure and resigns to accept the secondary importance of politics in the twenty-first century. Some scholars have speculated with a Luhmannian style of politics (as discussed in his posthumous Politik der Gesellschaft, 2000) as flexible complex of contingent operations without any aims of steering. 
For disputing the disappearance of politics thesis, it would be worth discussing, which kinds of politics as an activity have remained, without even a mention, outside Rüb's narrative. His systemic view presupposes a state- or government-centred politics from above. The chapter on parties is the only one in which the opposed points of view appear at all, and even there the internal party structure and its conformist tendencies get the upper hand. The view of parties as a voice from below (in the sense of Albert O. Hirschman's Exit, Voice and Loyalty, 1970) or the fair regulation of the competition between parties are not discussed at all.

Other types of politics as contingent action in the sense of contestation of the given have been discarded by Rüb. The politics of the twentieth century can hardly be understood without the activist movements of the workers, women, intellectuals, environmentalists and so on, which hardly appear inside the existing chapters at all. The contingency of the contestation of the status quo from below does not, strangely enough, interest Rüb at all. Is this because of the assumption that they are movements of those who are not 'system-relevant persons', to quote a widely used but horrible slogan of our corona times.

Equally surprising is that the parliaments and their politics of dissensus and debate in fact receive no independent mention, although they could be regarded as the radical antipode for the extremist politics of paranoia and killing. The parliamentary style of politics is the best approximation for the ideal type of a symmetric politics, based on fair play and respect for adversaries as well as an institutionalised search for opposed points of views submitted to a through debate in plena and committees. Still, the parliamentary style of politics is also a counter-force to what Weber calls the everyday rule of bureaucracy as well as to the populist 'politics of masses', discussed by Rüb. At least within the Westminster parliament the contingency of politics was well practised before the nineteenth century, and today parliaments are the most important counterweights to the rule of experts and specialists, who would leave for politics only the role of an ex post adaptation.

Friedbert Rüb has written a thought-provoking book, which contains numerous important insights and comments as well as presentations of largely unknown texts and viewpoints, which I have, however, left outside my review. They disappear within his big picture as he considers politics as being subordinated to 'the society' in a rather traditional systemic view. It is therefore that his historical theses on the rise and disappearance of the 'century of politics' are anything but convincing.

\title{
Competing Interests
}

The author has no competing interests to declare.

\begin{abstract}
How to cite this article: Palonen, Kari. 2021. "Book Review: Das Jahrhundert der Politik. Eine Geschichte des 20. Jahrhunderts im Lichte ihrer Politikbegriffe by Friedbert Rüb, Nomos, 2020, 682 pages. ISBN: 978-3-8487-6613-0." Redescriptions: Political Thought, Conceptual History and Feminist Theory 24(1), 76-80. DOl: https://doi.org/10.33134/rds.347
\end{abstract}

\section{Submitted: 07 March $2021 \quad$ Accepted: 01 June $2021 \quad$ Published: 22 July 2021}

Copyright: (c) 2021 The Author(s). This is an open-access article distributed under the terms of the Creative Commons Attribution 4.0 International License (CC-BY 4.0), which permits unrestricted use, distribution, and reproduction in any medium, provided the original author and source are credited. See http://creativecommons.org/licenses/by/4.0/. 